
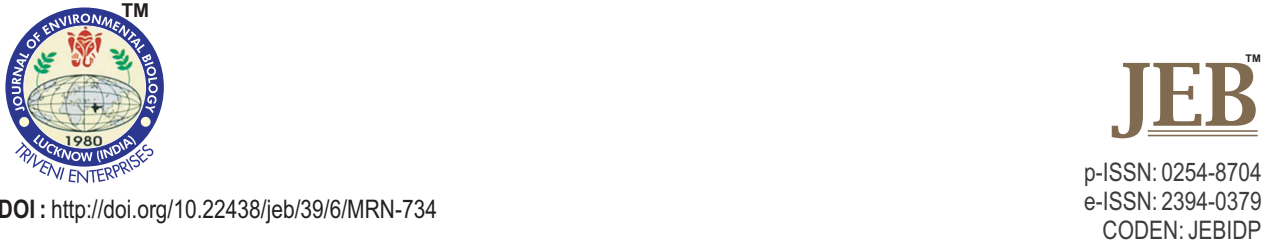

\title{
Soil organic carbon, dehydrogenase activity and fluorescein diacetate as influenced by contrasting tillage and cropping systems in Vertisols of Central India
}

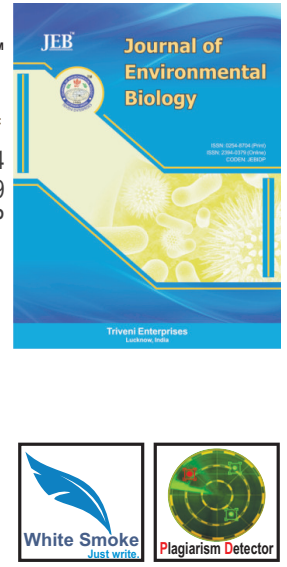

Authors Info

A. Kumar ${ }^{1 *}$, V.N. Mishra, A.K. Biswas ${ }^{3}$ and J. Somasundaram

'Division of Soil Physics, ICAR-Indian Institute of Soil Science, Nabibagh, Berasia Road, Bhopal-462 038, India

${ }^{2}$ Department of Soil Science and Agricultural Chemistry, Indira Gandhi Krishi Vishwavidyalaya, Krishak Nagar, Raipur -492 012, India

${ }^{3}$ Division of Soil Chemistry and Fertility, ICAR-Indian Institute of Soil Science, Nabibagh, Berasia Road, Bhopal 462 038, India

*Corresponding Author Email : awanish09_raj@yahoo.co.in

\section{Key words}

Cropping systems

Dehydrogenase activity

Fluorescein diacetate activity

Soil biological parameters

Tillage systems

Publication Info

Paper received : 29.08.2017

Revised received : 19.02 .2018

Re-revised received : 23.03.2018

Accepted: 23.04.2018

\section{Abstract}

Aim : The present study aimed to compare the effects of different tillage systems and cropping systems on soil biological activity in terms of soil organic carbon, labile carbon, dehydrogenase activity, fluorescein diacetate activity and crop productivity.

Methodology : The yield data of different cropping systems were converted in soybean grain equivalent yield using minimum support price based on 2015 and expressed in $q$ ha. ${ }^{-1}$. Soil samples were collected randomly from 2-3 locations from the plots at the end of $3^{\text {rd }}$ crop cycles at $0-5$ and $5-15 \mathrm{~cm}$ depths during April 2014 with the help of core sampler and processed. The soil samples were analysed using standard analytical procedures.

Results : Within tillage system, soil organic carbon was recorded higher in reduced tillage $(0.67 \%)$, compared to notillage $(0.66 \%)$ and conventional tillage $(0.62 \%)$ at $0-5 \mathrm{~cm}$ depth. The labile carbon in surface soil $(0-5 \mathrm{~cm})$ followed same trend of soil organic carbon, whereas at $5-15 \mathrm{~cm}$ depth, it followed the trend : no-tillage > reduced tillage > conventional tillage. Furthermore, soil enzymatic activity was significantly affected by the imposed tillage systems. The results of dehydrogenase activity reported higher in no-tillage system compared to reduced and conventional tillage; whereas fluorescein diacetate hydrolysis was reported higher in reduced tillage followed by no-tillage and conventional tillage at surface soil $(0-5$ $\mathrm{cm})$. Pearson correlation $(r)$ showed significant correlations between soil

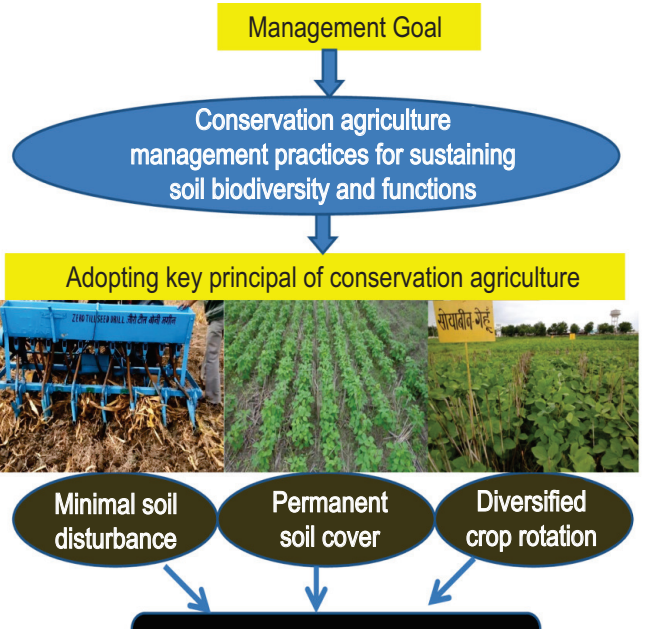

Improve soil biological activity as well as soil health organic carbon and soil biological parameters. It was inferred that cropping system had a significant effect on soybean grain equivalent yield at end of $3^{\text {rd }}$ crop cycles. The results of this study also confirmed effectiveness of studied parameters as soil indicators owing to sensitivity towards management practices.

Interpretation : Soil microbial activities greatly influenced with depth as in the upper layer than 5-15 cm depth. Significantly positive correlation between soil organic carbon and microbial activities indicated enhanced microbial biodiversity, maintaining a better environment for stabilizing soil quality due to tillage and cropping systems applied. 


\section{Introduction}

Conservation agriculture technology convenes to three key principles: minimal soil disruption, i.e. reduced tillage or notillage and direct sowing/planting; permanent soil cover, i.e. retention of crop residue/cover crops/inter-cropping and; diversified crop rotation to inhibit weeds residents, insects and diseases (Derpsch, 2001). No-tillage, ensures more storage of crop residue on surface of the soil, which results lower temperature and higher soil moisture with in effect to improve microbial activity, better soil aggregation and improvement in soil properties, such as soil organic carbon and nitrogen content and shrinkage $\mathrm{C}: \mathrm{N}$ ratio than conventional tillage (Derpsch et al., 2010; Benitio, 2010; Celik et al., 2011).

The suitable management practices of soil to perform are sustainable crop productivity and to maintain or increase soil quality (Aziz et al., 2009) and soil quality have to be a combination of physical, chemical and biological properties sensitive to management (Islam and Weil, 2000; Aparicio and Costa, 2007). Soil physical and chemical properties have been extensively used to measure soil quality around the world (Mukherjee and Lal, 2014; Kumar et al., 2017). However, soil functions typically change slowly, and consequently significant variations may occur for several years (Pupin et al., 2009, Gajda et al., 2013). In contrast, soil biological functions as an activity of soil microorganisms and/or activity of enzymes are sensitive to soil management practices and also due to sudden environmental changes, and providing sensitive information on changes in soil quality (Melero et al., 2010).

Soil organic carbon is considered as a key indicator of soil quality as well as soil health and it supports various momentous soil functions by providing energy, substrates and biological diversity to support biological activity, which affects aggregation (important for habitat space, oxygen supply, and preventing soil erosion), infiltration (important for leaching, runoff, and crop water uptake), and decomposition (important for nutrient cycling) (Franzluebbers, 2010). Herrick and Wander (1997) reported that different pool of SOC special functions at different characteristics of soil quality, such as fate of ionic and non-ionic complexes, the increase of cation exchange capacity and long term stability of micro-aggregate. Microbial enzymes have vital role in soil and are used to measure the soil quality and influence of soil management (Mohammadi, 2011; Pupin et al., 2009). Soil enzymes are important in catalyzing numerous essential reactions, necessary for existing processes of micro-organisms in soils and the stabilization of soil structure, decomposition of organic wastes, organic matter formation, and nutrient cycling, hence playing an important role in agriculture.

The soil biological activities are considered as dynamic properties and in continuous change in soil atmosphere. Conditions of soil in different agro-ecosystem are unstable for applied management practices. Hence, the management practices such as tillage, type and amount of fertilizer and crop rotations have great impact on soil biological properties. There is relatively very little information available on the effect of tillage and cropping systems on soil biological properties in tropical/ subtropical environment region, particularly for the Indian Vertisol (Kumar et al., 2017). In view of the above, the present study was carried out to evaluate the effect of different tillage and cropping systems on soil biological properties in terms of soil organic carbon, labile carbon, dehydrogenase activity and fluorescein diacetate.

\section{Materials and Methods}

Along-term field experiment (three years old) was started during August, 2011 with three contrasting tillage namely notillage, reduced tillage and conventional tillage in combination with crop four cropping systems on crop yield and soil properties under rainfed vertisols of Central India at the experimental station of ICAR- Indian Institute of Soil Science, Bhopal, India. Soils under the research farm was classified as clayey textural class (Vertisols, Isohyperthermic Typic Haplustert) with 58\% clay, $22 \%$ silt and $20 \%$ sand in the first $0-15 \mathrm{~cm}$ layer. The climate of the experimental site was characterised as hot sub humid type, with mean annual air temperature, mean annual rainfall and potential evapotranspiration of $25^{\circ} \mathrm{C}, 1130$ and $1400 \mathrm{~mm}$, respectively.

The experiment had a split-plot design with three tillage system (No-tillage, Reduce tillage and Conventional tillage) as the main plot and four crop systems namely [Soybean + Pigeon pea (2:1), Soybean - Wheat, Maize + Pigeon pea (1:1), Maize Gram] as the sub plot with a size of $10 \times 5 \mathrm{~m}(50 \mathrm{~m} 2)$ replicated thrice. The conventional tillage consisted of deep summer ploughing after residue burning and passed 3 to 4 tillage operations using tine cultivator, followed by sowing in kharif and rabi crops. The reduced tillage consisted of one pass tillage operation using duck foot cultivator and sowing through zero till seed drill in kharif and rabi crops and no-tillage consisted of sowing/planting crops into undisturbed soil by opening a narrow slot of sufficient width and depth to cover the seed using zero till seed drill. Soil samples were collected from two incremental depths $(0-5$ and $5-15 \mathrm{~cm})$ randomly, 2-3 locations in a plot in the month of April 2014 at the end of $3^{\text {rd }}$ crop cycle.

Therefore, at each depth, 36 soil samples [ 3 tillage (main treatments plots), 3 replicates and 4 cropping systems (sub treatments plots)] and total 72 soil samples were studied. These samples were air dried in a screen house grained with wooden mortal and pestal, passed through a $2.0 \mathrm{~mm}$ sieve after removing large plant material, and analysed for soil biological properties. Organic carbon content of the soil sample was determined by the method of Walkley and Black, (1934). The labile soil carbon was determined by potassium permanganate $\left(\mathrm{KM}_{\mathrm{n}} \mathrm{O}_{4}\right)$ oxidizable method as suggested by Blair et al. (1995). Soil dehydrogenase activity was determined by the method of Casida et al. (1964) using 3\% Triphenyltetrazolium chloride and colour intensity of TPF was recorded at $485 \mathrm{~nm}$ with a spectrophotometer. Soil fluorescence diacetate activity was estimated by the method of 
and Adam et al. (2001) using potassium phosphate buffer (pH 7.6) and absorbance of the filtrates were recorded at $490 \mathrm{~nm}$ with a spectrophotometer. The soil organic carbon, labile carbon, dehydrogenase activity, fluorescence diacetate activity and yield data were analysed using two way analysis of variance (ANOVA) technique following the split plot design. The data analysis was done with SPSS windows, version 11.0. The significance of the treatment effect was determined by $\mathrm{F}$ - test, and to compare the significance difference between two treatments, least significance difference $($ LSD) was estimated at $p<0.05$ level of significance.

\section{Results and Discussion}

The higher labile carbon and soil organic carbon concentration was recorded at surface layer $(0-5 \mathrm{~cm})$ and its concentration decreased with increasing depth. Among different tillage system evaluated, reduced tillage and no-tillage registered significantly $(p<0.05)$ higher soil organic carbon and labile carbon compared to conventional tillage at $0-5 \mathrm{~cm}$. Similarly, at $5-15 \mathrm{~cm}$ depth, reduced tillage and no-tillage registered significantly $(p<0.05)$ higher soil organic carbon compared to conventional tillage (Table 1). Regardless the soil depths, tillage had significant effect $(p<0.05)$ on labile carbon, soil organic carbon, whereas, cropping systems and interaction (tillage $x$ cropping system) effect on soil organic carbon was non-significant ( $p>0.05)$, but interaction between tillage and cropping systems had positive $(p<0.05)$ effect on labile carbon. Increased soil organic carbon and labile carbon at $0-5 \mathrm{~cm}$ depth under reduced tillage and notillage than conventional tillage was possibly attributed to minimum soil disturbances and crop residue retention helps in increasing soil carbon in the surface layers. Similarly, Hati et al. (2014) and McCarty et al. (1998) reported that conservation tillage, particularly no-tillage leads to a higher soil organic carbon concentration in the top layer of the soil $(0-5 \mathrm{~cm})$ and alters its distribution within the soil profile. In addition, conservation tillage maintains soil temperature variations, and enhancing soil moisture can also support better microbial activity in surface soil. In contrast under conventional tillage, results findings corroborated with the Bhattacharyya et al. (2009) and Dou et al. (2008) found conservation tillage namely no-tillage significantly increased the size of soil organic carbon and labile pools of carbon compared with conventional tillage only at surface layer. According to Weil et al. (2003), labile or active carbon pool, which is readily available to microbes are different from a highly recalcitrant or passive carbon pool, i.e., slowly altered by microbial activities. This fraction of carbon pool serves as a sensitive indicator like change in microbial biomass cabon, soil quality as influenced by the management practices (Islam and Weil, 2000; Li et al., 2012).

The results revealed that higher labile carbon under reduced tillage and no-tillage at surface layer $(0-5 \mathrm{~cm})$, indicated that soil quality improved under these practices compared to conventional practices. Many researchers have reported that soils under long-term no-tillage and reduced tillage systems recorded higher carbon concentration in the soil surface than conventional tillage (Thomas et al., 2007; Lopez-Fando and Pardo, 2009). Results of the present study were congruent with the findings of Bhattacharya et al. (2012), who concluded from a 6 years study that reduction in tillage intensity led to a significantly

Table 1 : Oxidizable soil organic carbon, labile carbon in soils under contrasting tillage and cropping systems of rainfed Vertisols of Central India

\begin{tabular}{|c|c|c|c|c|c|}
\hline \multirow{2}{*}{$\begin{array}{l}\text { Tillage } \\
\text { system } \\
\text { (TS) }\end{array}$} & \multirow{2}{*}{ Cropping systems (CS) } & \multicolumn{2}{|c|}{ Soil organic carbon (\%) } & \multicolumn{2}{|c|}{ Labile carbon } \\
\hline & & $0-5 \mathrm{~cm}$ & $5-15 \mathrm{~cm}$ & $0-5 \mathrm{~cm}$ & $0-15 \mathrm{~cm}$ \\
\hline \multirow[t]{5}{*}{ CT } & Soybean + P. Pea (2:1) & 0.64 & 0.55 & 353.86 & 146.63 \\
\hline & Soybean - Wheat & 0.59 & 0.48 & 324.35 & 94.72 \\
\hline & Maize + P. Pea (1:1) & 0.61 & 0.52 & 309.70 & 116.24 \\
\hline & Maize - Gram & 0.64 & 0.54 & 339.28 & 119.12 \\
\hline & Mean & 0.62 & 0.52 & 331.80 & 119.18 \\
\hline \multirow[t]{5}{*}{ RT } & Soybean + P. Pea (2:1) & 0.68 & 0.58 & 423.74 & 257.77 \\
\hline & Soybean - Wheat & 0.66 & 0.53 & 397.47 & 135.32 \\
\hline & Maize + P. Pea (1:1) & 0.67 & 0.60 & 364.82 & 145.74 \\
\hline & Maize - Gram & 0.67 & 0.55 & 428.40 & 150.18 \\
\hline & Mean & 0.67 & 0.57 & 403.61 & 172.25 \\
\hline \multirow[t]{5}{*}{ NT } & Soybean + P. Pea (2:1) & 0.66 & 0.59 & 398.03 & 263.09 \\
\hline & Soybean - Wheat & 0.66 & 0.56 & 376.30 & 169.26 \\
\hline & Maize + P. Pea (1:1) & 0.63 & 0.58 & 317.22 & 181.02 \\
\hline & Maize - Gram & 0.68 & 0.59 & 334.52 & 179.46 \\
\hline & Mean & 0.66 & 0.58 & 356.52 & 198.21 \\
\hline \multicolumn{6}{|l|}{ LSD } \\
\hline \multirow[t]{3}{*}{$(p<0.05)$} & TS & $0.003^{*}$ & $0.002^{*}$ & $\mathrm{~S}^{*}$ & $\mathrm{~S}^{*}$ \\
\hline & CS & $0.266^{\mathrm{NS}}$ & $0.42^{\mathrm{NS}}$ & $\mathrm{S}^{*}$ & $\mathrm{~S}^{*}$ \\
\hline & TXCS & $0.830^{\mathrm{NS}}$ & $0.755^{\mathrm{NS}}$ & $0.389^{\mathrm{NS}}$ & $0.15^{\mathrm{NS}}$ \\
\hline
\end{tabular}

NT-no tillage; CT-conventional tillage; RT-reduced tillage; TS-tillage system; CS-cropping system; NS- non significant at $p>0.05 ; S^{*}$-significant at $p<0.05$ 
higher soil organic carbon accumulation in the surface soil layer $(0-5 \mathrm{~cm})$, in the Indian Himalayas.

Among the cropping systems compared, soybean+ pigeon pea (2:1) recorded significantly higher soil organic carbon and labile carbon followed by maize- gram than maize+ pigeon pea (1:1) at $0-5 \mathrm{~cm}$ depth and almost similar trend was observed at $5-15 \mathrm{~cm}$ depth at the end of third crop cycle. The higher carbon under both cropping systems is possible due to less soil disruption, addition of above (leaf litter) and below (higher root biomass) ground biomass, legume in rotation/intercropping coupled with crop residue management in the top layer $(0-5 \mathrm{~cm})$. Further, above all these involvements help in net mineralization of carbon. Salinas-Darcia et al. (1997) reported that increase in soil organic carbon concentration in reduced tillage could make these systems more sustainable over long term carbon sequestration in soil. A global data analysis indicated that carbon sequestration rates peak in 5 to 10 years with a change from mouldboard plough to no-tillage and soil organic carbon reaching a new equilibrium in 15 to 20 years (West and Post, 2002).

Tillage systems had significant $(p<0.05)$ effect on dehydrogenase activity and fluorescence diacetate enzyme activity (Table 2). In general, conservation agriculture practices retaining crop residue, to protect soil surface from direct sun light and maintaining temperature and moisture in soil can also contribute positive effect on soil enzymatic activity. Parihar et al. (2016) was reported that long-term tillage and crop rotations and their interactions had significant effect on soil dehydrogenase activity and fluorescein diacetate hydrolysis enzyme activity for
0-30 cm soil depth. The higher fluorescence diacetate hydrolysis indicates contribution of several enzymes, involved in decomposition of soil organic matter/ crop residue. In general, surface layer $(0-5 \mathrm{~cm})$ recorded significantly higher microbial activity as compared to lower soil depth. Irrespective of soil depths, significantly higher dehydrogenase activity and fluorescence enzyme activity were recorded under reduced tillage compared to no tillage than conventional tillage practices.

The data inferred that enzymatic activity decreased with increasing soil depths. It was further inferred that cropping systems showed significant $(p<0.05)$ effect under $0-5$ and 5-15 $\mathrm{cm}$ depth in both crop cycles. Among the cropping systems compared, significantly higher dehydrogenase and fluorescenc activity was recorded in soybean + pigeon pea (2:1) followed by maize - gram cropping system in both the depth. Brandan et al. (2012) and Gajda et al. (2013) also reported that higher soil microbial enzymatic activities due to conservation agriculture with legume crop in rotation as compared to conventional tillage. The enzyme activity is commonly used as an indicator of biological activity in soils. This enzyme is considered to exist as an integral part of intact cells but does not accumulate extracellularly in the soil. Oxidation of soil organic matter by dehydrogenase is achieved by transferring protons and electrons from substrates to acceptor and is considered to be linked with respiration pathway of microorganisms (Das and Verma, 2011). Availability of organic matter, soil temperature and soil moisture significantly affect the dehydrogenase activity of soil. Madejon et al. (2007) and Tao et al. (2009) reported higher dehydrogenase activity in conservation agriculture with legume crop in rotation as compared to

Table 2 : Oxidizable soil organic carbon, labile carbon in soils under contrasting tillage and cropping systems of rainfed Vertisols of Central India

\begin{tabular}{|c|c|c|c|c|c|}
\hline \multirow{2}{*}{$\begin{array}{l}\text { Tillage } \\
\text { system } \\
\text { (TS) }\end{array}$} & \multirow{2}{*}{ Cropping systems (CS) } & \multicolumn{2}{|c|}{ Dehydrogenase activity (DHA) } & \multicolumn{2}{|c|}{ Fluorescein diacetate (FDA) } \\
\hline & & $0-5 \mathrm{~cm}$ & $5-15 \mathrm{~cm}$ & $0-5 \mathrm{~cm}$ & $5-15 \mathrm{~cm}$ \\
\hline \multirow[t]{5}{*}{ CT } & Soybean + P. Pea $(2: 1)$ & 146.63 & 35.64 & 35.64 & 10.31 \\
\hline & Soybean - Wheat & 94.72 & 35.33 & 35.33 & 14.17 \\
\hline & Maize + P. Pea (1:1) & 116.24 & 36.74 & 36.74 & 8.40 \\
\hline & Maize - Gram & 119.12 & 32.11 & 32.11 & 10.55 \\
\hline & Mean & 119.18 & 34.96 & 34.96 & 10.86 \\
\hline \multirow[t]{5}{*}{ RT } & Soybean + P. Pea $(2: 1)$ & 257.77 & 46.79 & 46.79 & 15.11 \\
\hline & Soybean - Wheat & 135.32 & 50.25 & 50.25 & 10.68 \\
\hline & Maize + P. Pea (1:1) & 145.74 & 45.27 & 45.27 & 10.65 \\
\hline & Maize - Gram & 150.18 & 45.88 & 45.88 & 22.17 \\
\hline & Mean & 172.25 & 47.05 & 47.05 & 14.65 \\
\hline \multirow[t]{5}{*}{ NT } & Soybean + P. Pea (2:1) & 263.09 & 51.12 & 51.12 & 9.24 \\
\hline & Soybean - Wheat & 169.26 & 45.61 & 45.61 & 7.36 \\
\hline & Maize + P. Pea (1:1) & 181.02 & 42.25 & 42.25 & 8.09 \\
\hline & Maize - Gram & 179.46 & 46.95 & 46.95 & 12.96 \\
\hline & Mean & 198.21 & 46.48 & 46.48 & 9.41 \\
\hline \multirow{4}{*}{$\begin{array}{l}\text { LSD } \\
(p<0.05)\end{array}$} & & & & & \\
\hline & TS & $\mathrm{S}^{*}$ & $\mathrm{~S}^{*}$ & $\mathrm{~S}^{*}$ & $\mathrm{~S}^{*}$ \\
\hline & CS & $S^{*}$ & $0.201^{\mathrm{NS}}$ & $0.201^{\mathrm{NS}}$ & $S^{*}$ \\
\hline & TXCS & $0.15^{\mathrm{NS}}$ & $0.137^{\mathrm{NS}}$ & $0.137^{\mathrm{NS}}$ & $\mathrm{S}^{*}$ \\
\hline
\end{tabular}

NT-no tillage; CT-conventional tillage; RT-reduced tillage; TS-tillage system; CS-cropping system; NS- non significant at $P>0.05 ; S^{*}$-significant at $p<0.05$ 
Table 3 : Relationship between soil organic carbon (SOC) and biological properties of soil under different tillage and cropping systems

\begin{tabular}{lll}
\hline Related soil parameters & Correlated coefficient $(\mathbf{r})$ & Linear equation \\
\hline SOC-LC & $0.72^{*}$ & $\mathrm{Y}=1043.1 \mathrm{x}-313.36$ \\
SOC-DHA & $0.64^{*}$ & $\mathrm{Y}=11478.8 \mathrm{x}-582.09$ \\
SOC-FDA & $0.77^{* *}$ & $\mathrm{Y}=176.19 \times-7158$ \\
\hline
\end{tabular}

SOC - Soil organic carbon, LC - Labile carbon, DHA- Dehydrogenase activity; FDA - Fluorescence diacetatehydrolysis activity, Statistical significance: ${ }^{*} p \leq 0.05,{ }^{* *} p \leq 0.01$.

conventional tillage. High soil organic matter/carbon in surface layer soil ensures availability of substrate for microbes and adequate aeration facilitates active aerobic decomposition, hence higher soil enzyme activity in top soil $(0-5 \mathrm{~cm})$. Higher dehydrogenase activity in deeper layer of conventional tillage compared to other system may be attributed to better aeration as frequent soil disturbance provides congenial condition to aerobic microbial community for growth and decomposition.

The inter-relationship of soil organic carbon and labile carbon were confidently inter-correlated with each other (Table 3). At surface layer $(0-5 \mathrm{~cm})$, organic carbon and labile carbon was significantly correlated $\left(r=0.72^{\star *}\right)$, indicating that under reduced tillage and no-tillage with residue retention/incorporation improved soil carbon in surface layer $(0-5 \mathrm{~cm}$ depth). The decrease in labile carbon under conventional tillage was accountable for intensive tillage. On the other hand, destruction of macro-aggregates has adverse effect on labile carbon resulting in loss of soil organic carbon (Madejon et al., 2007; Kumar et al., 2017). The soil organic carbon and dehydrogenase activity were significantly $(p<0.05)$ and positively correlated $\left(r=0.64^{* *}\right)$ with each other at surface layer (Table 3 ). Higher enzymatic activity in conservation tillage with legume crop in rotation as compared to conventional tillage has been reported earlier (Madejon et al., 2007; Tao et al., 2009). Soil organic carbon and fluorescein activity were also significantly correlated $\left(r=0.77^{* *}\right)$. The higher fluorescein activity under conservation tillage quantifies for involvement of numerous enzymes, involved in decay of soil organic matter/residue decomposition in soil.

Yield parameters recorded during third crop cycle and yield data were converted into soybean equivalent yield ( $q$ ha $^{-1}$ ) (Table 4). It was inferred that tillage had no significant effect $(p>0.05)$ on soybean grain equivalent even after completion of $3^{\text {rd }}$ crop cycles. However, cropping system had a significant effect during $3^{\text {rd }}$ crop cycles. Among the cropping systems studied, maize-gram recorded significantly $(p<0.05)$ higher yield followed by maize+ pigeon pea (1:1), soybean+ P. pea (2:1) and soybeanwheat at end of $3^{\text {rd }}$ crop cycles. Moreover, the interaction effect between tillage and cropping system did not show significant effect on crop yields. A slight increase in crop yield was observed under RT and NT compared to CT after completion of three crop cycles. Similarly, Tomar, (2008) concluded from ten year study that adoption of no-tillage had a slight advantage in terms of yield as compared to conventionally tilled plots in rice-wheat system in Vertisols. No-tillage, thus, not only resulted in slight improved yields, it also involved lower cost of production and account of saving in terms of fuel cost etc. The adoption of conservation agriculture, the beneficial effects are likely to increase over time due to improvement in soil quality (Tomar, 2008). The results of long term tillage experiment conducted during 2000-2010 at Indian Institute of Soil Science, Bhopal revealed that yield levels of conservation tillage soybean-wheat system was on par with conventional tillage, besides, greater saving of energy and labour under conservation tillage in Vertisols of Central India.

It was found that conservation tillage coupled with

Table 4 : Soybean grain equivalent yield $\left(q\right.$ ha $\left.{ }^{-1}\right)$ under contrasting tillage and cropping systems in Vertisols of Central India after $3^{\text {rd }}$ crop cycles

\begin{tabular}{lllll}
\hline & \multicolumn{4}{c}{ 2014-15 } \\
\cline { 2 - 5 } & \multicolumn{2}{c}{ Tillage systems (TS) } \\
\hline Cropping systems (CS) & CT & RT & NT & Mean \\
\hline Soybean + P pea (2:1) & 33.90 & 32.76 & 34.65 & 33.77 \\
Soybean- Wheat & 34.05 & 37.79 & 37.42 & 36.42 \\
Maize + P pea (1:1) & 43.45 & 42.12 & 44.56 & 43.38 \\
Maize - Gram & 49.24 & 52.67 & 53.10 & 41.67 \\
Mean & 40.16 & 41.34 & 42.43 & \\
LSD (p<0.05) & Tillage = NS & & & \\
& Cropping System = S & & & \\
& TXCS = NS & & & \\
\hline
\end{tabular}

TS-Tillage systems; CS-Cropping systems; NT-no tillage; CT-conventional tillage; RT-reduced tillage; NS- non significant at $p>0.05$; $S^{*}$-significant at $p<0.05$, Crop yields were converted into soybean grain equivalent yield using minimum support price based on MSP 2015 
residue management had a positive effect of microbial activity and also, enhancing the biological health of the soil. In addition, conservation agriculture practices not only sustained/increased organic carbon and microbial biodiversity but also favoured the crop. Indeed, the outcome of this study would be helpful in improving soil biodiversity, crop productivity as well as improving soil health in Verisols of Central India and similar agro-ecological region in South Asia.

\section{Acknowledgments}

First author sincerely thank Dr. S.K. Patil, ViceChancellor (IGKV, Raipur Chhattisgarh) and Director (ICARIndian Institute of Soil Science) for providing necessary facilities in carrying out this research work. Thanks are due to the Head, Dr. R.S. Chaudhary and Principal Scientist, Dr. K.M. Hati for their constant encouragement, support and guidance. Authors also thank all the scientific, field and laboratory staff of Soil Chemistry and Physics Division. The help rendered by Ms. Anusuiya Panda and Shamandeep Kaur Brar, Senior Research Fellow is heartily acknowledged.

\section{References}

Adam, G. and H. Duncan: Development of a sensitive and rapid method for the measurement of total microbial activity using fluorescein diacetate in a range of soils. Soil Biol. Biochem., 33, 943-951 (2001).

Aparicio, V.C. and J.L. Costa: Soil quality indicators under continuous cropping systems in the Argentinean Pampas. Soil Till. Res., 96, 155-165 (2007)

Aziz, I., T. Mahmood, Y. Raut, W. Lewis, R. Islam and R.R. Weil: Active organic matter as a simple measure of field soil quality. In: ASA International Meetings, Pittsburg, PA(2009).

Benitio, A.: Carbon accumulation in soil. Ten year study of conservation tillage and crop rotation in a semi-arid areas of Castile-Leon, Spain Aurora Sombrero. Soil Till. Res., 107, 64-70 (2010).

Bhattacharyya, R., V.P. Pandey, S.C. Kundu, S. Srivastva and A.K. Gupta: Effect of fertilization on carbon sequestration in soybean-wheat rotation under two contrasting soils and management practices in the Indian Himalayas. Aust. J. Soil Res., 47, 592-601 (2009).

Bhattacharya, R., M.D. Tuti, S. Kundu, J.K. Bishit and J.C. Bhatt: Conservation tillage impacts on soil aggregation and carbon pools in a sandy clay loam soil of the Indian Himalayas. Soil Sci. Soc. Am. J., 76, 617-627(2012).

Blair, G.J., R.D.B. Lefroy and L. Lisle: Soil carbon fractions based on their degree of oxidation, and the development of a carbon management index for agricultural system. Aust. J. Agri. Res., 46, 1459-1466 (1995)

Brandan, C.P., L. Jose Arzeno, J. Huidobro, B. Grumberg, C. Conforto, Hilton Sally, Gary D. Bending, Meriles, Jose M. Silvina and VargasGil: Long-term effect of tillage systems on soil microbiological, chemical and physical parameters and the incidence of charcoal rot by Macrophomina phaseolina (Tassi) Goid in soybean. Crop Prot., 40, 73-82 (2012).

Casida, L.E., D.A. J. Klein and T. Santoro: Soil dehydrogenase activity. Soil Sci., 98, 371-376 (1964).

Celik, I., Z.B. Barut, I. Ortas, M. Gok, A. Demirbas, Y. Tulun and C. Akpinar: Impacts of different tillage practices on some soil microbiological properties and crop yield under semi-arid Mediterranean conditions. Inter. J. Pl. Produ., 5, 237-254 (2011).

Das, S.K. and A. Varma: Role of enzymes in maintaining soil health. Soil Enzymology (Eds.: G. Shukla and A. Varma). Springer-Verlag Berlin Heidelberg. America. Soil Till. Res., 20, 241-270 (2011). DOI 10.1007/978-3-642-14225-3-2.

Derpsch, R.: Frontiers in conservation tillage and advances in conservation practice. In : Sustaining the Global Farm. (Eds.: D.E. Stott, R.H. Mohtar and G.C. Steinhardt), Purdue University and the USDAARS National Soil Erosion Research Laboratory, pp. 248254 (2001).

Derpsch, R., T. Friedrich, A. Kassam and L. Li Hongwen: Current status of adoption of no-till farming in the world and some of its main benefits. Inter. J.Agric. Biol. Eng., 3, 1-26 (2010).

Dou, F., A.L. Wright and F.M. Hons: Sensitivity of labile soil organic carbon to tillage in wheat-based cropping systems. Soil Sci. Soc. Am. J., 72, 1445-1453 (2008).

Franzluebbers, A.J.: Achieving soil organic carbon sequestration with conservation agricultural systems in the South Eastern United States. Soil Sci. Soc. Am. J., 74, 347-357 (2010).

Gajda, A.M., Oka B. Przew and Gawryjo K.ek.: Changes in soil quality associated with tillage system applied. Int. Agrophy., 27, 133-141 (2013). doi: 10.2478/v10247-012-0078-7.

Hati, K.M., R.S. Chaudhary, K.G. Mandal, K.K. Bandyopadhyay, R.K. Singh, N.K. Sinha, M. Mohanty, J. Somasundaram and R. Saha: Effects of tillage, residue and fertilizer nitrogen on crop yields, and soil physical properties under soybean-wheat rotation in Vertisols of Central India. Agric Res., 4, 48-56 (2014).

Herrich, J.E. and M.M. Wander: Relationship between soil organic carbon and soil quality in cropped and rangeland soils. The importance of distribution, composition and soil biological activity. Soil Process. Carbon Cyc., 28, 405-458 (1997).

Islam, K.R. and R.R. Weil: Soil quality indicator propertiesin Mid-Atlantic soils as influenced by conservation management. J. Soil Water Cons., 55, 69-78 (2000).

Kumar, A., J. Somasundaram, A.K. Biswas, N.K. Sinha, V.N. Mishra, R.S. Chaudhary, M. Mohanty, K.M. Hati, R. Saha and A.K. Patra: Shortterm effect of conservation agriculture practices on soil quality of a Vertisols in Central India. Appl. Biol. Res., 19, 26-34 (2017).

Li, Cheng-Fang, Li-XinYue, Zhi-Kui Kou, Zhi-Sheng Zhang, Jin-Ping Wang and Cou-Gui Cao: Short-term effects of conservation management practices on soil labile organic carbon fractions under a rape-rice rotation in central China. Soil Till. Res., 119, 3137 (2012).

Lopez-Fando, C. and M. T. Pardo: Changes in soil chemical characteristics with different tillage practices in a semi-arid environment. Soil Till. Res., 104, 278-284 (2009).

Madejon, E.F., J.M. Moreno Murillo and F. Pelegrn: Soil biochemical response to long-term conservation tillage under semi-arid Mediterranean conditions. Soil Till. Res., 94, 346-352 (2007).

McCarty, G.W. and J.J. Meisinger: Effects of $\mathrm{N}$ fertilizer treatments on biologically active $\mathrm{N}$ pools in soils under plow and no tillage. Biol. Fert. Soils., 24, 406-412 (1998).

Melero, S., R. Lupez-Garrido, E. Madejun, J.M. Murillo, K. Vanderlinden, R. Ordunez and F. Moreno: Carbon fractions and enzymatic activities in two cultivated dryland soils under conservation tillage. Proc. $19^{\text {th }}$ Congr. Soil Solutions for a Changing World, Brisbane, Australia (2010).

Mohammadi, K.: Soil microbial activity and biomass as influenced by tillage and fertilization in wheat production. American-Eurasian $\mathrm{J}$. Agric. Environ.,10, 330-337 (2011). 
Mukherjee, A., R. Lal and A.R. Zimmerman: Effects of biochar and other amendments on the physical properties and greenhouse gas emissions of an artificially degraded soil. Sci. Total Environ., 487, 26-36 (2014).

Parihar, C.M., M.R. Yadav, S.L. Jat, A.K. Singh, B. Kumar, S. Pradhan, D. Chakraborty, M.L. Jat, R.K. Jat, Y.S. Saharawat and O.P. Yadav: Long term effect of conservation agriculture in maize rotations on total organic carbon, physical and biological properties of a sandy loam soil in North-Western Indo Gangetic Plains. Soil Till. Res., 161, 116-128 (2016).

Pupin,B., F. Silva and E. Nahas: Microbial alterations of the soil influenced by induced compaction. Revista Brasileira de Ciencia do Solo., 33, 1207-1213 (2009).

Salinas-Garcia, J.R., F.E., Hons, J.E. Matocha: Long-term effects of tillage and fertilization on soil organic matter dynamics. Soil Sci. Soc. Am. J., 61, 152-159 (1997).

Tao, J., B. Griffiths, S. Zhang, X. Chen, M. Liu, F. Hu and H. Li: Effects of earthworms on soil enzyme activity in an organic residue amended rice-wheat rotation agro-ecosystem. Appl. Soil Ecol., 42, 221-226 (2009).

Thomas, G.A., R.C. Dalal and J. Stanle: No-till effects on organic matter, $\mathrm{pH}$, cation exchange capacity and nutrient distribution in a Luvisol in the semi-arid subtropics. Soil Till. Res., 94, 295-304 (2007).

Tomar, S.S.: Conservation agriculture for rice wheat cropping systems. J. Indian Soc. Soil Sci, 56, 358-356 (2008).

Walkley, A.J. and C.A. Black: An estimation of the digested method for determining soil organic matter and a proposed modification of the chromic acid titration method. Soil Sci., 37, 29-38 (1934).

Weil, R.R., R.K. Islam, A.M. Stine, J.B. Gruver and S.E. Samson-Liebig: Estimating active carbon for soil quality assessment: A simplified method for laboratory and field use. Am. J. Alter. Agril., 18,1-17 (2003).

West, T.O. and W.M. Post: Soil organic carbon sequestration rates by tillage and crop rotation: Global data analysis. Soil Sci. Soc. Am. J., 66,1930-1946 (2002).

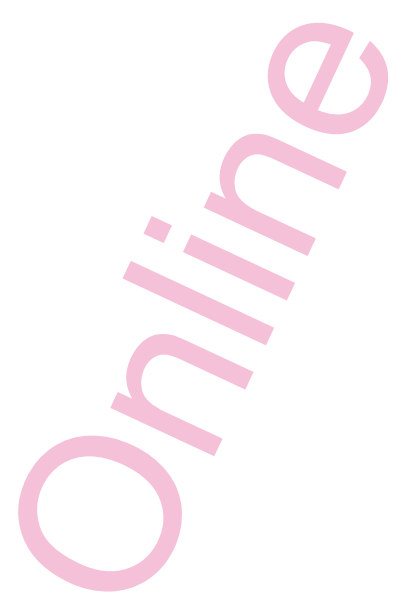

